\title{
Smoking Patterns and Physical Fitness in a Gurkha Infantry Battaliont
}

\author{
Major TO Jefferson, \\ MD(Pisa), MRCGP, DRCOG MIL, RAMC \\ ${ }^{*}$ RMO 2nd Bn 2nd KEO Gurkha Rifles, Church Crookham, Aldershot
}

SUMMARY: The aims of this paper are to illustrate the average tobacco consumption in an Infantry Battalion of the Brigade of Gurkhas in an attempt to relate this to fitness standards. The discernable smoking trends are compared with data published and unpublished from the British and other European Armies. The daily routine of a Gurkha soldier is described and the results of a basic fitness test are examined.

†Paper presented at Preventive Medicine Group Symposium, RAOC Training Centre, Deepcut, Surrey on 30 April 1985.

\section{Background}

Gurkha is the name given to Nepali soldiers who serve in the British Army. They have done so since 1815.

Most of the present day Gurkhas have been recruited in their home villages at the foot of the Himalayas. In these hamlets all the outside supplies must be carried by man or donkey.

The Nepali villager and his equivalent in the Army, the Gurkha soldier, are therefore well used to daily intensive physical effort often carrying weights uphill.

\section{Smoking Trends}

A questionnaire was devised and sent for completion to each soldier on the strength of the Unit. The results can be seen in Figure 1. There were no non-responders

to the questionnaire. Exactly 200 members of the battalion $(32 \%)$ were cigarette smokers.

The number of heavy smokers ( 20 cigarettes or more a day) were $42(6.5 \%)$. No pipe or cigar smokers were present in our population (Table 1).

The remaining 446 were either lifelong non-smokers, ex-smokers (here defined as abstention from cigarettes for longer than one year) or Khaini users. Khaini is a mixture of tobacco and lime which is placed between the gum and the lip and absorbed, but not smoked.

The majority of the 75 Khaini users were below the? age of 30 . This is only partly explained by the bias introduced by the high numbers of soldiers under 30 .

These figures compare favourably with figures from a survey carried out amongst young French Servicemen ${ }^{1}$.

Table 1

Breakdown of Male Personnel's tobacco consuming habits. 1st 7th Gurkha Rifles, 1984.

Cigarette Smokers

\begin{tabular}{cccccc}
\hline Daily & Age 18-30 & $\mathbf{3 1 - 3 5}$ & $\mathbf{3 6 - 4 0}$ & 41 and over & Total \\
\hline $1-9$ & 73 & 10 & 4 & 2 & 89 \\
$10-19$ & 49 & 15 & 2 & 1 & 67 \\
20 or more & 27 & 6 & 8 & 3 & 44 \\
\hline TOTAL & 149 & 31 & 14 & 6 & 200 \\
\hline
\end{tabular}

Non-Smokers (including 64 ex-smokers)

\begin{tabular}{lcccc}
\hline Age 18-20 & $\mathbf{3 1 - 3 5}$ & $\mathbf{3 6 - 4 0}$ & $\mathbf{4 1}$ and over & Total \\
\hline 295 & 49 & 24 & 3 & 371 \\
\hline
\end{tabular}

Khaini Eaters

\begin{tabular}{lcccc}
\hline Age 18-30 & $\mathbf{3 1 - 3 5}$ & $\mathbf{3 6 - 4 0}$ & 41 and over & Total \\
\hline 70 & 3 & 1 & 1 & 75 \\
\hline
\end{tabular}

${ }^{*}$ Fmrly RMO, 1st Bn 7th Duke of Edinburgh's Own Gurkha

Rifles. 


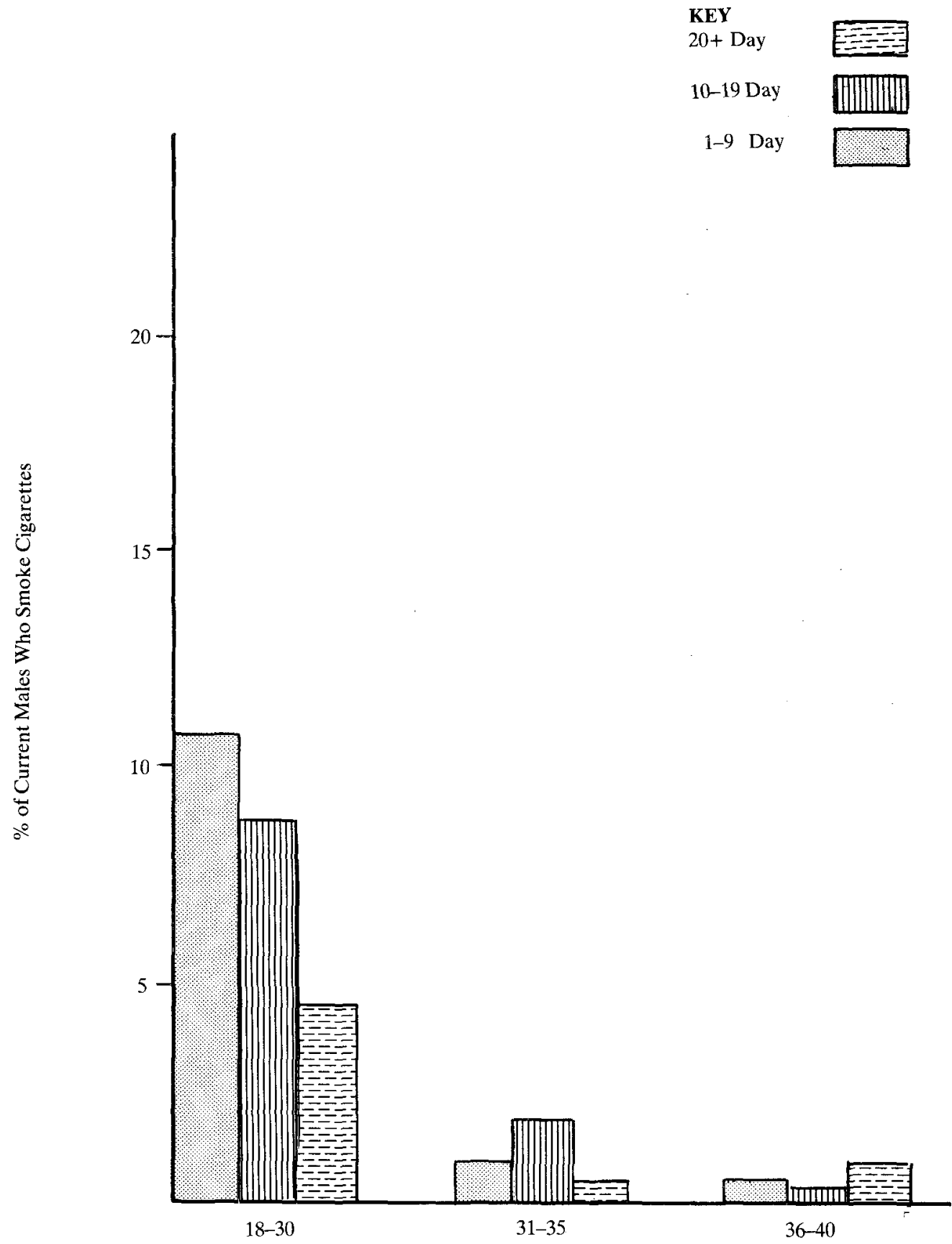

Figure 1 Cigarette Smoking Survey Results 1st 7th Gurkha Rifles 1984. Breakdown of Cigarette Smokers by Age and Consumption. The Group Aged 41 and Over is not represented because of the small population numbers involved. 
In that survey $73 \%(1,328)$ of young males beginning their military service in the French Armed Forces in 1980 smoked cigarettes, $34 \%$ (621 individuals) of this sample being heavy cigarette smokers. The total population of this study was 1,829 (Fig. 2).

The difference in percentage between cigarette smokers and non-smokers and also between heavy smokers in our sample and in the French survey is highly significant $(\mathrm{P}>0.001)$.

The same favourable comparison can be made with a British mechanized infantry battalion surveyed by the author in 1985 , in which $76.8 \%$ of the total strength of the unit were cigarette smokers with $61.3 \%$ being heavy cigarette smokers ( 20 or more a day).

These last data are in broad agreement with a survey of BAOR soldiers' smoking habits undertaken in 1980 (Crawford, personnal communication) and smoking surveys on British troops in the $60 \mathrm{~s}$ and $70 \mathrm{~s}^{2}$.

Data from Nepal on smoking habits of the young population are scarce, but one source claims that as many as $41 \%$ of youths above the age of five smoke in one District of $\mathrm{Nepal}^{3}$.

\section{The Daily Routine of a Gurkha Rifleman}

Table 2 is the half-weekly training programme of a Rifle Company. As can be seen approximately three hours a day are devoted to the physical fitness training programme, sports and field training take up another three hours a day.

Fitness training and sports are taken very seriously by all, as the results of the Basic Fitness Test (BFT) show.

\section{The Basic Fitness Test of January 1984}

The BFT consists of a first part of $1 \frac{1}{2}$ miles, which is considered a warm-up, partly run and partly walked, and a second part which is an individual best effort which must be completed within the time allocated, which increases with older age groups.

The BFT is mandatory for all ranks twice yearly and must be run wearing Combat boots.

In January 1984 the author's unit took its BFT as part of a competition with other Major Units in the Station. Half of the military personnel were selected by external assessors to run the test and given 24 hours' notice. The runners included the Commanding Officer. The results are given in Table 3.

As can be seen the pass rate was $100 \%$, and 235 out of 312 runners $(74 \%)$ arrived with a minute or more to spare at the finish line. No published data are available to compare these results with similar results from a British Major Unit.

\section{Discussion}

It is impossible to quantify the exact level of fitness of a group. This is especially so in the absence of cardiovascular data. The evidence which I have presented seems to leave little doubt that a Gurkha soldier is a very旡 fit individual who regards exercise as a part of his life. If is notable that 1st 7th Gurkha Rifles' results were bettered by a similar unit which ultimately won the competition.

It is also encouraging to note that the incidence o cigarette smoking is notably lower in a Gurkha battalion

Table 2

Half-Weekly Training Program for a Rifle Company 1st Battalion 7th Duke of Edinburgh's Own Gurkha Rifles

\begin{tabular}{|c|c|c|c|c|c|c|}
\hline Day & $0730-0800$ & Breakfast & $0900-1240$ & Lunch & 1345-1515 & $1515-1750$ \\
\hline Wednesday & BFT Training & & $\begin{array}{l}\text { Ambush } \\
\text { Lecture }\end{array}$ & & $\begin{array}{l}\text { English } \\
\text { Lesson }\end{array}$ & Sports \\
\hline Thursday & BFT Training & & $\begin{array}{l}\text { Section Fire } \\
\text { and Manoeuvre }\end{array}$ & & $\begin{array}{l}\text { Section Fire } \\
\text { and Manoeuvre }\end{array}$ & Sports \\
\hline Friday & BFT Training & & Patrol Practice & & $\begin{array}{l}\text { Battalion } \\
\text { Fatigues }\end{array}$ & Sports \\
\hline Saturday & BFT Training & & Weapon Care & & & \\
\hline
\end{tabular}

Table 3

Basic Fitness Test (BFT) of January 1984

1st Battalion 7th Duke of Edinburgh's Own Gurkha Rifles Pass Rate by Age Group and Timings

\begin{tabular}{ccccc}
\hline Age Group & Number Tested & $\begin{array}{c}\text { Pass > 1 Minute } \\
\text { Below Target Time }\end{array}$ & Normal Pass & Fail \\
\hline $40-44$ & 12 & 12 & NIL & NIL \\
$35-39$ & 26 & 23 & 3 & NIL \\
$30-34$ & 43 & 28 & 15 & NIL \\
29 or below & 231 & 172 & 59 & NIL \\
\hline TOTALS & 312 & 235 & 77 & NIL \\
\hline
\end{tabular}




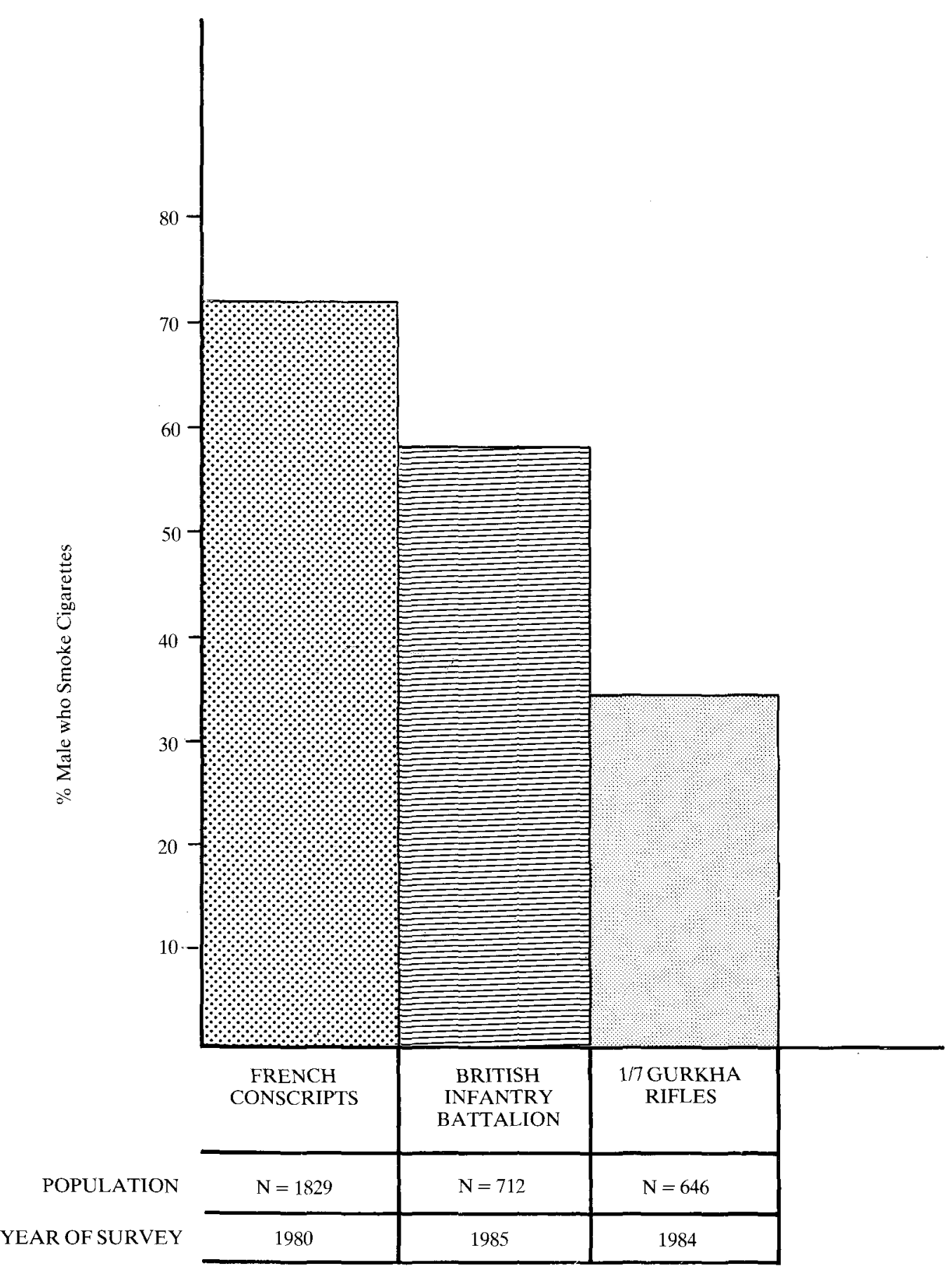

Figure 2 Cigarette Smoking Habits of French Conscripts, a British Mechanized Infantry Battalion and 1st 7th Gurkhā Rifles (excluding Khaini eaters). French Conscripts after J-G Bernard et al. $\mathbf{N}=$ Number 
than in its European counterparts. The Author has more recent evidence of an even lower percentage of smokers in another Gurkha unit ${ }^{4}$, an astonishing $11 \%$.

The reasons for this are not wholly clear, but the environment in the Brigade of Gurkhas and the education received while still recruits seem to have a beneficial effect. The absence of tobacco advertising in the Gurkha Service environment and certain areas of Nepal is probably beneficial as well.

\section{Acknowledgement}

The Author would like to thank Colonel I P Crawford GM, L/RAMC and Colonel C J Lewthwaite L/RAMC for the help received in writing this paper.

\section{REFERENCES}

1. Bernard J, et al. Le Tabagisme du Jeune Francais et le Service Militaire, Rev Epidmiol Sante Publique 1980; 28: 413-421.

2. Crowdy J P, Lewthwaite $\mathrm{C} J$ and Sowden $R$ R. Smoking: The Changing Habits of Male Adolescents. JR Army Med Corps $1975 ; 121$ : 126-131.

3. AnONymous. Percentage of Smokers in Jumla, The Rising Nepal, 20.10.83.

4. JEFFERSON T O. Smoking and the Soldier's Health, in British Army Review (Forthcoming).

\section{HONORARY CONSULTANTS TO THE ARMY}

Mr J S Garfield, MA, MChir, FRCP, FRCS has been appointed Honorary Consultant in Neurosurgery to the Cambridge Military Hospital with effect from 1 May 1986. This is a new appointment.

Dr Med Thomas O F Wagner has been appointed Honorary Consultant in Medicine to the Army in BAOR with effect from 1 May 1986.

Dr A L Muir, MD, FRCP(E) has been appointed Honorary Consultant in Medicine to the Army in Scotland with effect from 19 September 1986.

Professor Arthur K C Li has been appointed Honorary Consultant in Surgery to the Army in Hong Kong with effect from 21 September 1986.

Professor ULF C G Engzell, MD, PhD, has been appointed Honorary Consultant in Oto-RhinoLaryngology to the Army in Hong Kong with effect from 12 August 1986. 